\title{
Development of pyruvate oxidase-based amperometric biosensor for pyruvate determination
}

\author{
D. V. Knyzhnykova ${ }^{1,2}$, Ya. V. Topolnikova ${ }^{1}$, I. S. Kucherenko ${ }^{1}$, O. O. Soldatkin ${ }^{1,2}$ \\ ${ }^{1}$ Institute of Molecular Biology and Genetics, NAS of Ukraine \\ 150, Akademika Zabolotnoho Str., Kyiv, Ukraine, 03680 \\ ${ }^{2}$ Institute of High Technologies, Taras Shevchenko National University of Kyiv \\ 2, korp.5, Pr. Akademika Hlushkova, Kyiv, Ukraine, 03022 \\ kucherenko.i.s@gmail.com
}

\begin{abstract}
Aim. Development and optimization of the amperometric biosensor for pyruvate determination. Methods. Immobilized pyruvate oxidase was used as a biorecognition element of the biosensor, a platinum disc electrode, as an electrochemical transducer. Results. Different variants of immobilization of pyruvate oxidase were tested and the optimal one was chosen for the creation of a biorecognition element of the biosensor. Optimal concentrations of cofactors for the best performance of the pyruvate oxidase-based biosensor were selected. The developed biosensor demonstrated a high sensitivity to pyruvate and wide linear range. High selectivity of the proposed biosensor towards electrically active substances and other substrates present in real samples was shown. The biosensor is characterized by high signal reproducibility and operational stability over two weeks. Conclusions. The highly selective amperometric biosensor for determination of pyruvate in biological samples has been developed. Its analytical characteristics were studied. The biosensor can be further used for the pyruvate analysis in blood serum.
\end{abstract}

Ke y w o r d s: pyruvate, pyruvate oxidase, amperometric biosensor.

\section{Introduction}

Pyruvate is a simple keto acid, which plays a central role in the metabolism and carbohydrate conversions. Pyruvate is a key metabolite in a number of biochemical transformations associated with the catabolism in mitochondria. The main metabolic pathways of pyruvate are aerobic oxidation to oxaloacetate or an- aerobic conversion to lactate. Pyruvate oxidation involves the enzyme pyruvate dehydrogenase and is an intermediate step between glycolysis and Krebs cycle.

The pyruvate concentration in the blood normally ranges from $40-50$ to $100 \mu \mathrm{mol} / \mathrm{L}$ $[1,2]$. The pyruvate level increases when the aerobic processes intensify and at insufficient pyruvate utilization in the pyruvate dehydro-

(C) 2018 D. V. Knyzhnykova et al.; Published by the Institute of Molecular Biology and Genetics, NAS of Ukraine on behalf of Biopolymers and Cell. This is an Open Access article distributed under the terms of the Creative Commons Attribution License (http://creativecommons.org/licenses/by/4.0/), which permits unrestricted reuse, distribution, and reproduction in any medium, provided the original work is properly cited 
genase complex. A higher pyruvate concentration is observed in the cases of vitamin $\mathrm{B}_{1}$ deficiency, respiratory alkalosis (a sharp decrease in the level of carbon dioxide in the blood, accompanied by an increase in $\mathrm{pH}$ ), arsenic and mercury poisoning, and liver pathologies such as alcoholic cirrhosis, hepatitis, etc. [3].

An increased by 2-2.8 times concentration of pyruvate is also found in the serum and saliva of oral cancer patients. The evaluation of pyruvate concentration is considered as a new method of cancer screening [2, 4]. Additionally, an increased content of pyruvate in tissues typically indicates an imbalance in the systems of oxygen supply and consumption. The pyruvate concentration in the blood is an informative laboratory evidence of the adequacy of blood supply and tissue oxygenation or hypoxia.

In the clinical practice of emergency therapy, the pyruvate monitoring has not been implemented yet due to the selectivity problems - the pyruvate concentration in the blood is low whereas the concentration of electroactive interferents is quite high. The development of electrochemical biosensors can solve this problem.

To date, there are a number of biosensors for pyruvate measuring intended for clinical use. Thus, Gajovic et al. developed the biosensor based on recombinant pyruvate oxidase for the pyruvate determination in serum [3]. For the protection against intense interference from ascorbate, the electrode surface was coated with a dialysis membrane based on acetate and nitrocellulose. The biosensor demonstrated a limit of pyruvate detection of $30 \mu \mathrm{M}$ in calf serum, which, according to the authors, is suf- ficient for continuous monitoring of pyruvate in organs and tissues at hypoxia. Arai et al. immobilized pyruvate oxidase in the layer of a conductive redox polymer poly(mercapto- $p$ benzoquinone) by electropolymerization on the electrode surface [5]. Here, the polymer molecules functioned as a chain for the electrons transfer between the enzyme active center and the electrode surface. The dynamic range of this biosensor was from $1 \mu \mathrm{M}$ to $2 \mathrm{mM}$. Akyilmaz et al. developed a pyruvate oxidase-based biosensor to measure pyruvate and phosphate for clinical use. The enzyme was immobilized in gelatin and fixed by crosslinking with glutaraldehyde [6].

Unfortunately, none of the known biosensors for the pyruvate determination was accomplished and commercialized. Therefore, the purpose of this work was to develop an amperometric biosensor for quantitative analysis of pyruvate concentration in biological fluids. This is the extension and continuation of our previous work, where we described the amperometric biosensor system for the determination of lactate and pyruvate [7].

\section{Materials and Methods}

\section{Materials}

In this work we used pyruvate oxidase (PyrOx) from Aerococcus sp. (EC 1.2.3.3), activity $54 \mathrm{U} \cdot \mathrm{mg}^{-1}$, sodium pyruvate, bovine serum albumin, glycerol, polyvinyl alcohol photopolymer containing styrylpyridine groups (PVA-SbQ), magnesium nitrate, 25\% aqueous glutaraldehyde (GA) solution, acetylcholine chloride, choline chloride, glutamate chloride and HEPES from SigmaAldrich (USA), thiamine pyrophosphate 
(TPP) (lyophilisate for injection solutions) from Biofarma (Ukraine), and potassium dihydrogen phosphate $\left(\mathrm{KH}_{2} \mathrm{PO}_{4}\right)$ were from Helicon (Russia). Other inorganic compounds used in the work were of domestic production and had reagent purity grade.

Microparticles of silicalite were synthesized artificially in accordance with the method described in the previous paper [8].

\section{Design of amperometric transducers}

Platinum disk electrodes were manufactured in our laboratory using the following technology. $3 \mathrm{~mm}$ long platinum wire, $0.5 \mathrm{~mm}$ in diameter, was soldered with low-temperature Wood's alloy to the silver wire and placed into a glass capillary with outer diameter $3.5 \mathrm{~mm}$. The end of capillary with inserted platinum wire was sealed by soldering and used as a sensitive surface of the transducer. The electrode working part with inserted platinum wire was periodically treated with sandpaper and aluminum microparticles to restore the sensitivity of transducer.

\section{Preparation of bioselective elements}

A bioselective element of the biosensor was obtained by immobilization of the enzymes and auxiliary substances onto the surface of amperometric transducer. The initial solution consisted of $20 \%$ of PyrOx, $5 \%$ of BSA, $10 \%$ of glycerol in $100 \mathrm{mM}$ phosphate buffer, $\mathrm{pH}$ 6.5. Glycerol was added to stabilize the enzymes during their immobilization as well as to prevent early drying of the membrane and improve its adhesion to the transducer surface. Immobilization of PyrOx was performed in three different ways: cross-linking with glutaraldehyde, adsorption on silicalite, and entrapment into polymer PVA-SbQ.

\section{Measurement procedure}

A three-electrode scheme of the amperometric analysis was used. The working amperometric transducers, an auxiliary platinum electrode, and an $\mathrm{Ag} / \mathrm{AgCl}$ reference electrode were connected to the potentiostat PalmSens (PalmInstruments BV, the Netherlands). The 8-channel device $\mathrm{CH}-8$ multiplexer (PalmInstruments $\mathrm{BV}$, the Netherlands) connected to the potentiostat allowed receiving the signals simultaneously from eight working electrodes, but usually only two-three working electrodes were in operation simultaneously. The distance between the auxiliary platinum electrode and all working electrodes was stable over the entire measurement procedure and was approximately $5 \mathrm{~mm}$.

Chronoamperometric measurements ("amperometric detection" technique) were carried out at room temperature in an open measuring cell of $2.5 \mathrm{ml}$ volume at permanent stirring and constant potential of $+0.6 \mathrm{~V}$ vs Ag/AgCl reference electrode. The $50 \mathrm{mM}$ phosphate buffer $\left(\mathrm{KH}_{2} \mathrm{PO}_{4}-\mathrm{Na}_{2} \mathrm{HPO}_{4}\right)$, pH 6.5, was used as a working buffer, unless different stated. TPP and magnesium ions were necessary for the PyrOx activity and were added to the working buffer (several concentrations were used, as stated in the text). The biosensor connected to the potentiostat was immersed into the cell with working buffer and kept for several minutes with applied potential until stable baseline was obtained. Then certain aliquots of the model pyruvate solution were added and the biosensor's responses were recorded using the 
computer program. All experiments were carried out in at least three replicates.

\section{Results and Discussion}

The operation of amperometric biosensor for pyruvate determination is based on the enzymatic reaction (1) occurring in the bioselective membrane:
Selection of the optimal working potential Firstly, influence of the applied potential on the current from the platinum disk electrodes was investigated. The potential directly influenced oxidation (or reduction) of hydrogen peroxide on the electrode surface, and thus the biosensor responses were greatly dependent on the potential. We studied the biosensor

$$
\text { pyruvate }+ \text { phosphate }+\mathrm{H}_{2} \mathrm{O}+\mathrm{O}_{2} \underset{\text { TPP, } \mathrm{FAD}, \mathrm{Mg}^{2+}}{\stackrel{\text { Pyruate oxidase }}{\longrightarrow}} \text { acetyl phosphate }+\mathrm{H}_{2} \mathrm{O}_{2}+\mathrm{CO}_{2}
$$

The reaction results in pyruvate oxidation with the formation of electrochemically active hydrogen peroxide. Application of a positive potential on the electrode stimulates the reaction of hydrogen peroxide decomposition (2) and generation of electrons, which are directly registered using the amperometric transducer.

$$
\mathrm{H}_{2} \mathrm{O}_{2} \stackrel{+0.6 \mathrm{~V}}{\longrightarrow} 2 \mathrm{H}^{+}+\mathrm{O}_{2}+2 \mathrm{e}^{-}
$$

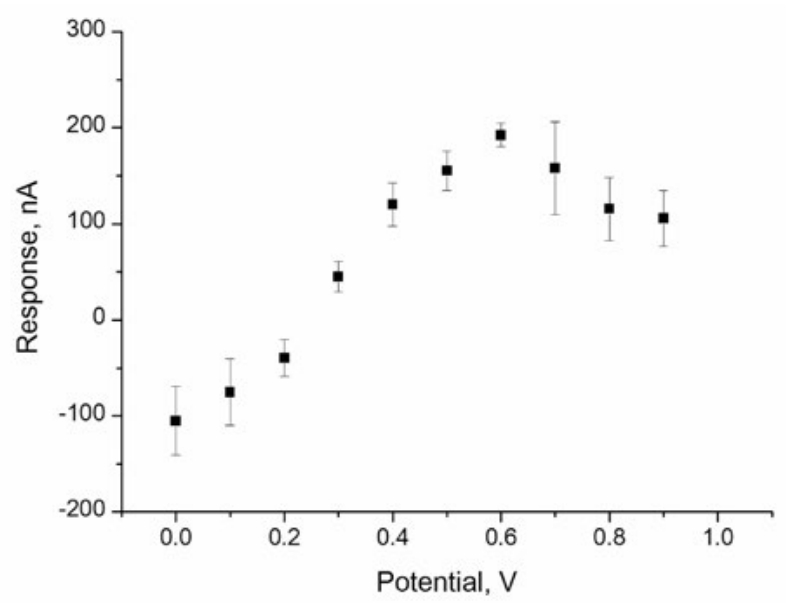

Fig. 1. Dependence of the amperometric transducer responses on applied potential. Hydrogen peroxide concentration $1 \mathrm{mM}$. Measurements in $50 \mathrm{mM}$ phosphate buffer, $\mathrm{pH} 6.5$ responses in the potential range from $-0.5 \mathrm{~V}$ to $+0.9 \mathrm{~V}$ with $0.1 \mathrm{~V}$ step vs $\mathrm{Ag} / \mathrm{AgCl}$ reference electrode (Fig. 1).

It was found that the responses to $\mathrm{H}_{2} \mathrm{O}_{2}$ could be recorded at any potential, but the highest response values were obtained at $+0.6 \mathrm{~V}$. Relatively high responses were observed also at $0 \mathrm{~V}$, but with negative current due to hydrogen peroxide reduction. This result could be very promising since at $0 \mathrm{~V}$ [an] impact of interfering substances is much lower, but the noise of baseline was very high in this case and accurate detection of target substances was impossible. Thus for the further research $0.6 \mathrm{~V}$ was taken as the optimum value.

Optimization of the immobilization conditions for PyrOx

An important step in the bioselective membrane formation is immobilization of biological material on the transducer surface with maximum maintenance of the enzyme activity. The following methods of immobilization were tested: cross-linking using GA, adsorption on a silicalite layer, entrapment in polymer PVASbQ. The same amount of enzyme was used to compare different methods. 
PyrOx immobilization with GA was investigated firstly. The enzyme solution was mixed with low-concentration glutaraldehyde aqueous solution in [the] 1:1 ratio and immediately afterwards the obtained mixture was deposited onto the transducer's surface. The bioselective elements with different GA mass fraction $(0.15 \%, 0.35 \%$ and $0.25 \%)$ were used. Then the transducers were kept in the open air at room temperature for $15 \mathrm{~min}$ to allow crosslinking of PyrOx and BSA, and washed with the working buffer afterwards.

The second method of enzyme immobilization was adsorption on silicalite. The silicalite suspension (mass fraction 10\%) in $50 \mathrm{mM}$ phosphate buffer, $\mathrm{pH} 6.5$, was deposited onto the transducer's sensitive region. The latter was heated to $100^{\circ} \mathrm{C}$ for $5 \mathrm{~min}$ to improve the attachment of silicalite to the surface. Next, the transducers were cooled down and PyrOx solution was deposited over the obtained silicalite layer. Afterwards, the transducer was kept in the air at room temperature until complete drying (15 min).

The third immobilization method was [the] PyrOx entrapment in photopolymerized PVA$\mathrm{SbQ}$. To form the membrane, PyrOx solution and PVA-SbQ solution (a mass fraction 13.3\%) were mixed in the 1:1 ratio; the obtained mixture was deposited onto the transducer surface and exposed for 25 min to UV irradiation with the ultraviolet lamp.

Analytical characteristics of [the] biosensors based on different methods of immobilization (sensitivity, linear range of pyruvate determination, [a] lower limit of detection, [an] upper limit of dynamic range, noise and drift of the baseline) are shown in the Table 1. It can be seen that the biosensors with PyrOx adsorption on silicalite and PyrOx photopolymerization in PVA-SbQ had the widest linear range of detection. The biosensors with immobilization in a GA drop (mass fraction $0.15 \%$ ) and photopolymerization in PVA-SbQ demonstrated the highest sensitivity to pyruvate whereas the biosensors using PyrOx immobilization via GA (mass fractions $0.25 \%$ and $0.35 \%$ ) were almost insensitive to pyruvate. The greatest noise of the baseline was observed for the biosensors with the enzyme immobilization via GA ( $0.15 \% \mathrm{GA})$, whereas the lowest baseline noise - for those with PyrOx adsorption on silicalite. An advantage of the biosensors with PyrOx immobilization

\section{Table 1. Comparison of analytical characteristics of biosensors created using different methods of} immobilization

\begin{tabular}{|l|c|c|c|c|c|}
\hline \multirow{2}{*}{\multicolumn{1}{|c|}{ Analytical characteristics }} & \multicolumn{5}{|c|}{ Type of immobilization } \\
\cline { 2 - 6 } & GA $0.15 \%$ & GA $0.25 \%$ & GA 0.35\% & $\begin{array}{c}\text { Adsorption } \\
\text { on silicalite }\end{array}$ & $\begin{array}{c}\text { Photopolymeri-zation } \\
\text { in PVA-SbQ }\end{array}$ \\
\hline Sensitivity, $\mathrm{nA} / \mathrm{mM}$ & 22.1 & 1.5 & 2.9 & 11.5 & 23.7 \\
Linear range, $\mathrm{mM}$ & $0.15-5$ & $0.9-3$ & $0.3-11$ & $0.1-7$ & $0.01-5$ \\
Lower limit of detection, $\mu \mathrm{M}$ & 17.7 & 308 & 170 & 6.0 & 5.1 \\
Upper limit of dynamic range, $\mathrm{mM}$ & 9.2 & 3.6 & 17.0 & 8.1 & 6.8 \\
Noise of baseline, $\mathrm{nA}$ & 0.18 & 0.14 & 0.13 & 0.06 & 0.09 \\
Drift of baseline, $\mathrm{nA} / \mathrm{min}$ & 0.1 & 0.15 & 0.07 & 0.05 & 0 \\
\hline
\end{tabular}


in a GA drop $(0.35 \%$ GA) was the largest value of the upper limit of dynamic range.

Of all methods of enzyme immobilization, photopolymerization of PyrOx in PVA-SbQ was characterized by the highest sensitivity to pyruvate, the lowest limit of detection and the best operational stability; therefore, in further research we used this method.

\section{Influence of cofactor concentrations}

As known, the reaction of pyruvate oxidation to acetyl phosphate and hydrogen peroxide occurs in the presence of additional substances: phosphate as the second substrate, TPP and bivalent magnesium cation as cofactors of PyrOx. $\mathrm{Mg}^{2+}$ plays essential role in the binding of TPP, thus the $\mathrm{Mg}^{2+}$-TPP complex is formed, which is required for PyrOx. Therefore, it was necessary to study the impact of each substance and to determine their optimal concentrations.

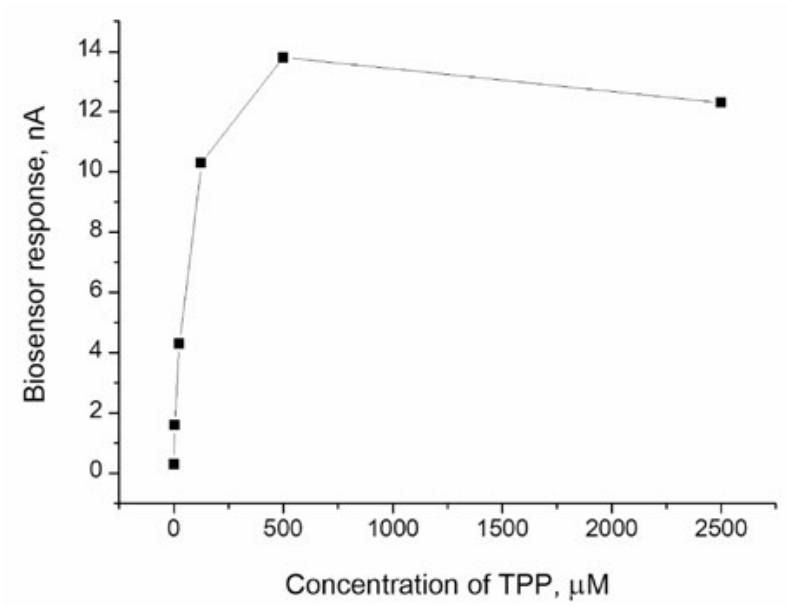

Fig. 2. Dependence of biosensor response on TPP concentration. Concentration of pyruvate was $500 \mu \mathrm{M}$, magnesium - $5 \mathrm{mM}$. Measurements were carried out in $50 \mathrm{mM}$ phosphate buffer, $\mathrm{pH} 6.5$, at a constant potential of $+0.6 \mathrm{~V}$ vs $\mathrm{Ag} / \mathrm{AgCl}$ reference electrode
First, the influence of TPP concentration on the biosensor response to pyruvate was studied. In the experiment, TPP in concentrations from $1 \mu \mathrm{M}$ to $2500 \mu \mathrm{M}$ was added to the working buffer. As seen (Fig. 2), the response increased up to $500 \mu \mathrm{M}$, so this concentration was taken in further work as optimal.

To find the optimal concentration of $\mathrm{Mg}^{2+}$, the biosensor sensitivity to pyruvate was tested in the range $20-2400 \mu \mathrm{M} \mathrm{Mg}^{2+}$. As seen from Fig. 3, the highest response was observed at the magnesium concentration of $120 \mu \mathrm{M}$ whoch was taken as optimal in the further experiments.

The value of biosensor response depends also on the concentration of the phosphoric acid ions, which are the substrate in the PyrOxcatalyzed enzymatic reaction. Therefore, the effect of the phosphate concentration in the buffer solution on the biosensor response was investigated. The developed biosensor for py-

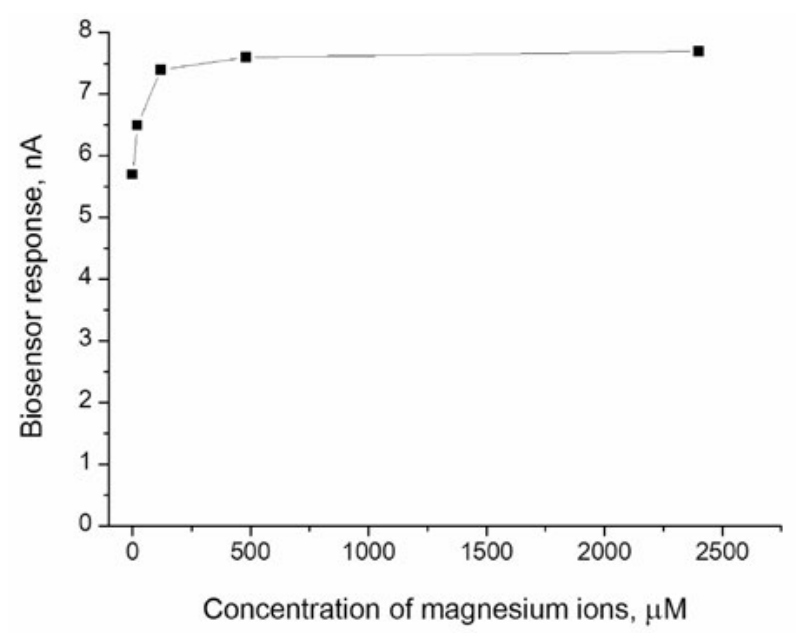

Fig. 3. Dependence of biosensor response on magnesium ions concentration. Concentration of pyruvate was $250 \mu \mathrm{M}$, TPP $-0.5 \mathrm{mM}$. Measurements were performed in $50 \mathrm{mM}$ phosphate buffer, $\mathrm{pH} 6.5$, at a constant potential of $+0.6 \mathrm{~V}$ vs $\mathrm{Ag} / \mathrm{AgCl}$ reference electrode 


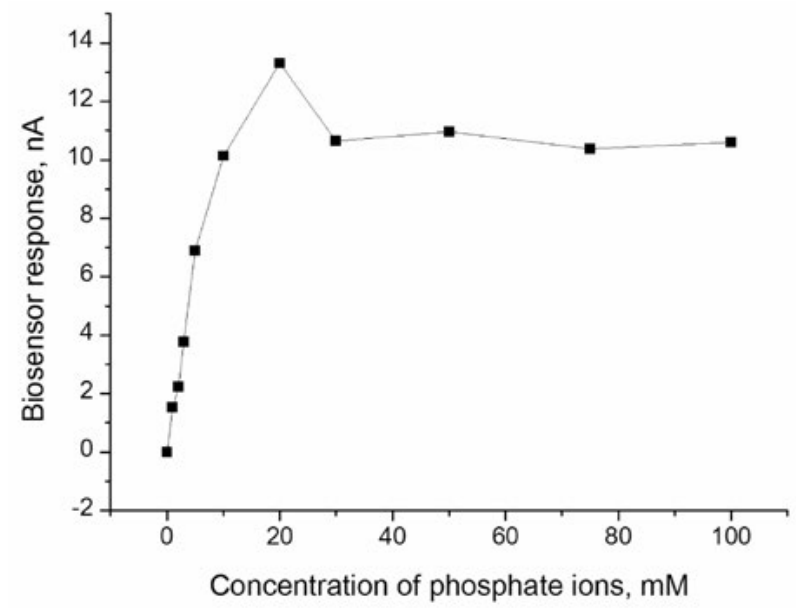

Fig. 4. Dependence of the biosensor response on concentration of phosphoric acid ions. Concentration of pyruvate was $500 \mu \mathrm{M}$, TPP $-500 \mu \mathrm{M}, \mathrm{Mg}^{2+}-120 \mu \mathrm{M}$. Measurements were carried out in $25 \mathrm{mM}$ HEPES buffer, $\mathrm{pH} 7.4$, at a constant potential of $+0.6 \mathrm{~V}$ vs $\mathrm{Ag} / \mathrm{AgCl}$ reference electrode

ruvate analysis is planned to be combined with other biosensors, in which HEPES-based buffer is used as a working buffer. Therefore, operation of the PyrOx-based biosensor was investigated in the HEPES working buffer containing ions of phosphoric acid of various concentrations ( $1-100 \mathrm{mM})$. As seen (Fig. 4), an increase in the phosphoric acid concentration up to $20 \mathrm{mM}$ caused essential increase of the biosensor response values whereas no changes occurred at higher phosphoric acid concentration. Therefore, the working buffer with $20 \mathrm{mM}$ phosphates was used in further experiments

\section{Analytical characteristics of the biosensor}

The biosensor main analytical characteristics were determined under optimized working conditions. A typical calibration curve is shown in Fig. 5. As known, the lower limit of detection corresponds to the substrate concentration,

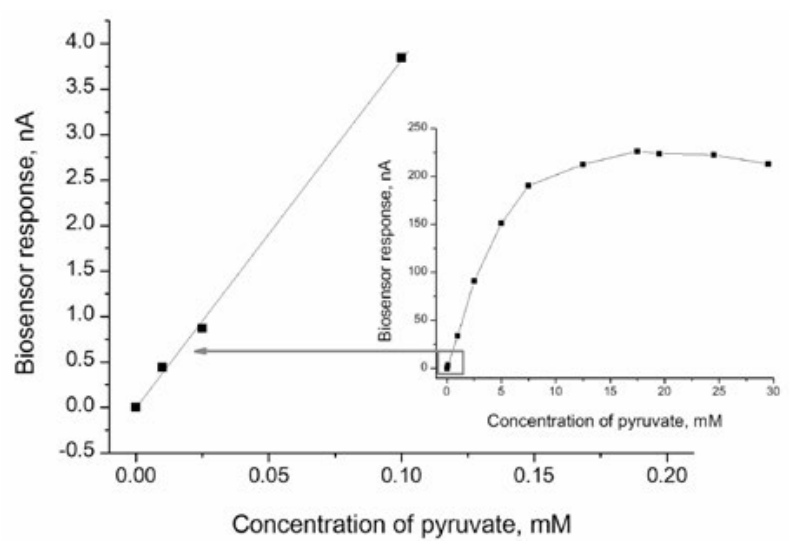

Fig. 5. Dependence of response of PyrOx-based biosensor on pyruvate concentration. Concentration of magnesium ions $-120 \mu \mathrm{M}$, TPP $-0.5 \mathrm{mM}$. Measurements were carried out in $50 \mathrm{mM}$ phosphate buffer, $\mathrm{pH} 6.5$, at a constant potential of $+0.6 \mathrm{~V}$ vs $\mathrm{Ag} / \mathrm{AgCl}$ reference electrode

at which the biosensor response is three-times higher than the value of baseline noise. The limit of detection of pyruvate was determined as $8.1 \mu \mathrm{M}$ and slightly differed for each individual biosensor. The linear range of pyruvate determination was $0.01-5 \mathrm{mM}$ ], sensitivity to pyruvate was $31.06 \mathrm{nA} / \mathrm{mM}$. The linear part of calibration curve is described by the equation $\mathrm{I}=31.06 * \mathrm{C}+1.88\left(\mathrm{R}^{2}=0,989\right)$, where $\mathrm{I}$ is the current value corresponding to the steady-state response (nA), C - pyruvate concentration (mM).

Reproducibility of responses is one of the main working characteristics of biosensors. However, the washing-out of immobilized components from the bioselective membrane and the enzyme inactivation are observed in the course of operation. Therefore, the next step in our work was to test the reproducibility of the biosensor response during several hours of continuous work. The biosensor responses to $500 \mu \mathrm{M}$ pyruvate were measured 
15 times over one working day (Fig. 6, A); no noticeable decrease in responses was observed. The relative standard deviation of the biosensor responses was $3.7 \%$.

The operational stability is another very important characteristic of the biosensor, which determines the possibility of its continuous application. To evaluate operational stability of the PyrOx-based biosensor, three responses to $500 \mu \mathrm{M}$ pyruvate were measured once the biosensor was prepared and after its storage dry at $+4{ }^{\circ} \mathrm{C}$ before the next use. In a few days, the biosensor was unfrozen, three responses were obtained, and the biosensor was frozen again. In total, the test lasted for 14 days. The results obtained are presented in Fig. 6, B. During the experiment, a slight decrease in responses was observed (final decrease was $18 \%$ ). Thus, it is possible to proceed with the measurements for at least 14 days or even more if an additional calibration is carried out.

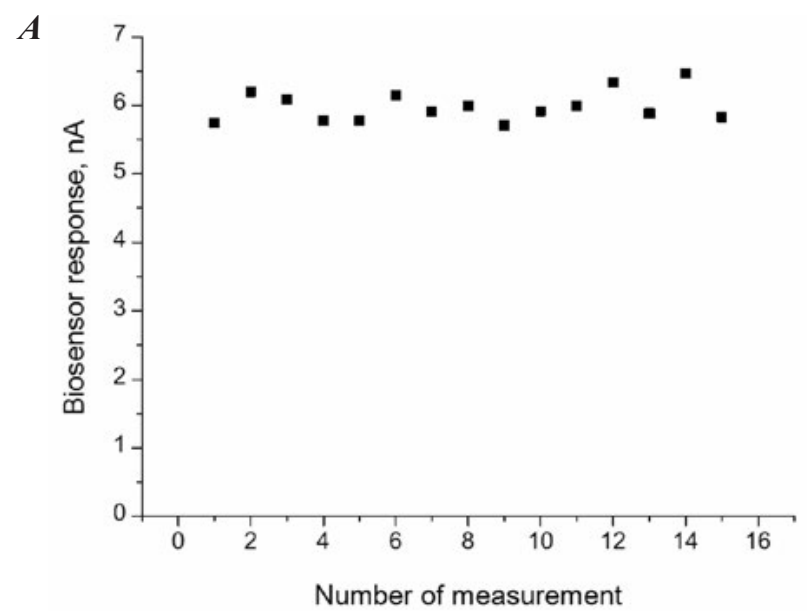

\section{Selectivity of the biosensor}

The mediator-free biosensor with high working potential, used in the work, creates the prerequisites for the oxidation of a number of electrically active compounds other than tested, which are present in biological samples. For the improvement of the biosensor selectivity, prior to the creation of bioselective elements an additional layer of semi-permeable poly$m$-phenylenediamine (PPD) membrane was deposited onto the electrode, which limits the diffusion of interfering substances to its surface. The procedure of formation of an additional polymer membrane consisted in electropolymerization of phenylenediamine molecules on the transducer surface. This technique has been developed in our laboratory earlier [9]. It has been shown that after deposition of an additional PPD membrane the amperometric transducer was characterized by high selectivity towards electrically active substances such as ascorbic acid and cysteine.

$\boldsymbol{B}$

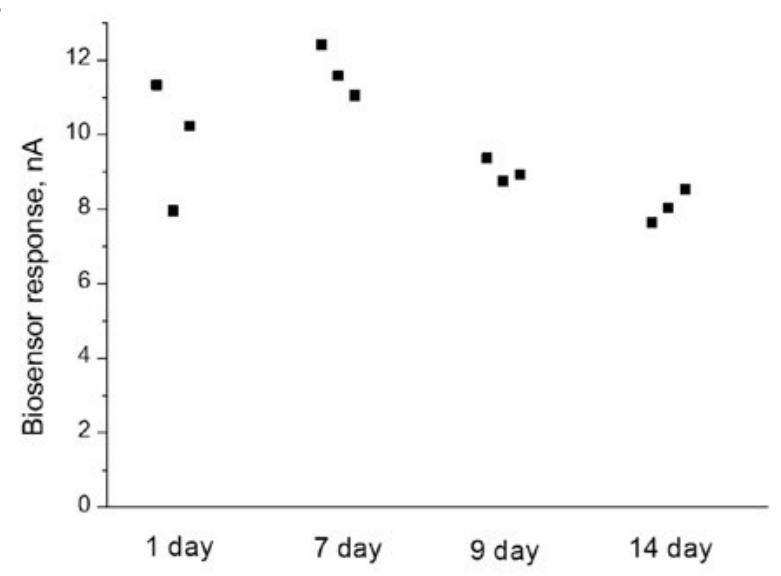

Fig. 6. Reproducibility of biosensor response to pyruvate during continuous work (A) and operational stability of biosensor during 14 days (B). Concentration of pyruvate was $500 \mu \mathrm{M}$, magnesium ions $-120 \mu \mathrm{M}, \mathrm{TPP}-500 \mu \mathrm{M}, \mathrm{PO}_{4}{ }^{3-}-$ $20 \mathrm{mM}$. Measurements were carried out in $25 \mathrm{mM}$ HEPES buffer, $\mathrm{pH} 7.4$, at a constant potential of $+0.6 \mathrm{~V} \mathrm{vs} \mathrm{Ag} / \mathrm{AgCl}$ reference electrode 
It is highly probable that the developed PyrOx-based biosensor will be integrated into a multibiosensor (i.e. will function together with other biosensors) to determine several key metabolites (glucose, lactate, etc.). Therefore, it was important to avoid any cross impact of other substrates on the pyruvate analysis. Hence, the biosensor sensitivity to possible interfering substrates such as lactate, choline, acetylcholine, glutamate and glucose was evaluated. It was found that the addition of other than pyruvate substrates to the measuring cell of the PyrOx-based biosensor had no impact on its response, which proves high selectivity of the biosensor to pyruvate.

\section{Conclusions}

The amperometric biosensor was developed and optimized for the pyruvate determination. Different variants of the PyrOx immobilization were analyzed to create a bioselective element, PyrOx photopolymerization in PVA-SbQ was selected as optimal. The determined optimal concentrations of cofactors and substrates for the PyrOx-based biosensor were as follows: magnesium $-120 \mu \mathrm{M}$, thiamine pyrophosphate $-500 \mu \mathrm{M}$, phosphoric acid ions $20 \mathrm{mM}$. The developed biosensor had sensitivity to pyruvate of $31.06 \mathrm{nA} / \mathrm{mM}$ and a linear working range of 0.01 to $5 \mathrm{mM}$. The biosensor was shown to be highly selective towards electrically active substances and other substrates, which actually can be present in real samples. Additionally, the biosensor is characterized by high signal reproducibility over the working day and operational stability during two weeks. The developed biosensor is planned to be used for the pyruvate measurement in biological fluids.

\section{Acknowledgements}

This work was supported by the Program of NAS of Ukraine "Smart sensor devices of a new generation based on modern materials and technologies".

\section{REFERENCES}

1. Pundir CS, Narwal V, Batra B. Determination of lactic acid with special emphasis on biosensing methods: A review. Biosens Bioelectron. 2016;86:777-790

2. Bhat MA, Prasad K, Trivedi D, Rajeev BR, Battur $H$. Pyruvic acid levels in serum and saliva: A new course for oral cancer screening? J Oral Maxillofac Pathol. 2016;20(1):102-5. doi: 10.4103/0973-029X.180955.

3. Gajovic N, Beinyamin G, Warsinke A, Scheller FW, Heller A. Operation of a miniature redox hydrogelbased pyruvate sensor in undiluted deoxygenated calf serum. Anal Chem. 2000;72(13):2963-8.

4. Bhat A, Bhat M, Prasad K, Trivedi D, Acharya $S$. Estimation of Pyruvic acid in serum and saliva among healthy and potentially malignant disorder subjects - a stepping stone for cancer screening? J Clin Exp Dent. 2015;7(4):e462-5.

5. Arai G, Noma T, Habu H, Yasumori I. Pyruvate sensor based on pyruvate oxidase immobilized in a poly(mercapto-p-benzoquinone) film. $J$ Electroanal Chem. 1999; 464(2): 143-8.

6. Akyilmaz E, Yorganci E. Construction of an amperometric pyruvate oxidase enzyme electrode for determination of pyruvate and phosphate. Electrochim Acta. 2007; 52(28): 7972-7.

7. Topolnikova YV, Knyzhnykova DV, Kucherenko IS, Dzyadevych SV, Soldatkin OO. Development of amperometric biosensor system for simultaneous determination of pyruvate and lactate. Sens Electron Microsyst Technol. 2017; 14(4): 13-26.

8. Kucherenko IS, Soldatkin OO, Kasap BO, Öztürk S, Akata B, Soldatkin AP, Dzyadevych SV. Elaboration of Urease Adsorption on Silicalite for Biosensor Creation. Electroanalysis. 2012; 24(6): 1380-5.

9. Soldatkina OV, Kucherenko IS, Pyeshkova VM, Alekseev SA, Soldatkin OO, Dzyadevych SV. Improvement of amperometric transducer selectivity 
using nanosized phenylenediamine films. Nanoscale Res Lett. 2017;12(1):594

\section{Розробка амперометричного біосенсора на основі піруватоксидази для визначення пірувату}

Д. В. Книжникова, Я. В. Топольнікова, І. С. Кучеренко, О. О. Солдаткін

Мета. Розробка та оптимізація роботи амперометричного біосенсора для визначення пірувату. Методи. Застосовано амперометричний біосенсор з іммобілізованою піруватоксидазою як біоселективний елемент та платинові дискові електроди як перетворювачі. Результати. Перевірено різні варіанти іммобілізації піруватоксидази та обрано оптимальний для створення біоселективного елементу біосенсора. Підібрано оптимальні концентрації кофакторів для найкращої роботи біосенсора на основі піруватоксидази. Розроблений біосенсор демонстрував високу чутливість до пірувату та широкий лінійний діапазон роботи. Було показано високу селективність запропонованого біосенсора відносно електроактивних речовин та інших субстратів, що можуть бути присутніми в реальних зразках. Біосенсор характеризується високою відтворюваністю сигналу та операційною стабільністю протягом 2 тижнів. Висновки. Розроблено високоселективний амперометричний біосенсор для визначення пірувату у біологічних зразках та досліджено його аналітичні характеристики. В подальшому даний біосенсор може бути використано для визначення пірувату у сироватці крові.

К л ю ч о в і с л о в а: піруват, піруватоксидаза, амперометричний біосенсор.

\section{Разработка амперометрического биосенсора на основе пируватоксидазы для определения пирувата}

Д. В. Книжникова, Я. В. Топольникова, И. С. Кучеренко, А. А. Солдаткин

Цель. Разработка и оптимизация работы амперометрического біосенсора для определения пирувата. Методы. Использовано амперометрический біосенсор с иммобилизованной пируватоксидазой как биоселективным элементом и платиновые дисковые электроды как преобразователи. Результаты. Проверено разные варианты иммобилизации пируватоксидазы и выбрано оптимальный для создания биоселективного элемента биосенсора. Подобрано оптимальные концентрации кофакторов для наилучшей работы биосенсора на основе пируватоксидазы. Разработанный биосенсор демонстрировал высокую чувствительность к пирувату и широкий линейный диапазон работы. Было показано хорошую селективность предложенного биосенсора относительно электроактивных веществ и других субстратов, которые могут присутствовать в реальных образцах. Биосенсор характеризуется высокой воспроизводимостью сигнала и операционной стабильностью на протяжении двух недель. Выводы. Разработан высокоселективный амперометрический биосенсор для определения пирувата в биологических образцах и исследованы его аналитические характеристики. В дальнейшем данный биосенсор может быть использован для определения пирувата в сыворотке крови.

К л юч е в ы е с л о в а: пируват, пируватоксидаза, амперометрический биосенсор.

Received 08.09.2017 